Original research article

Received: 29 April 2018

DOI: $10.20901 / \mathrm{pm} .55 .4 .04$

\title{
No-platforming and Safe Spaces: Should Universities Censor more (or less) Speech than the Law Requires?'
}

\author{
ERIC HEINZE \\ Queen Mary, University of London
}

\begin{abstract}
Summary
How should higher education respond to legally mandated limits on hateful, discriminatory, or provocative speech? Should public universities fortify government rules in the name of equal dignity for vulnerable groups, by imposing even further restrictions of their own? Or should they oppose such restrictions in the name of free speech? Or should they do neither, seeking neither amplification nor repeal, instead simply joining in whatever the government status quo happens to be, as they would do with most other background legal rules? This article advocates the second position: through a brief examination of "no-platforming" and "safe space" policies, it is argued that, within fullyfledged democracies, viewpoint-selective censorship is always indefensible for higher education. Examples are drawn from high-profile controversies involving far-right speakers as well as pro- and anti-Israel speech. Viewpointbased censorship generates one of two scenarios, neither of which coheres
\end{abstract}

1 The author would like to thank Kristian Ekeli, Rosa Freedman, Neve Gordon, Rebecca Gould, and Adrian Howe for their helpful comments, as well as Hrvoje Cvijanović and the Faculty of Political Sciences at the University of Zagreb for the invitation to present ideas in this article at the International Symposium Hate Speech, Symbols and Memories in June 2018. Some of the ideas are adopted from previously published opinion pieces including: "UC Berkeley, Donald Trump and the muddled ethics of no-platforming", The Raw Story, 14 February 2017, https:// www.rawstory.com/2017/02/uc-berkeley-donald-trump-and-the-muddled-ethics-of-no-platforming/ (retrieved 1 Aug 2018); "Israel, no-platforming - and why there's no such thing as 'narrow exceptions' to campus free speech", The Conversation, 30 April 2017, https://theconversation.com/israel-no-platforming-and-why-theres-no-such-thing-as-narrow-exceptions-tocampus-free-speech-76907 (retrieved 1 Aug 2018); and "Are you sitting comfortably? How safe spaces became dangerous", Free Speech Debate, 5 December 2017, http://freespeechdebate.com/discuss/are-you-sitting-comfortably-how-safe-spaces-became-dangerous/ (retrieved 1 Aug 2018). 
with the mission of higher education. One the one hand, no-platformers' declared principles could never be applied with ethical coherence without becoming so broad as to require massive censorship. On the other hand, if those principles are to apply only rarely, then they lose internal consistency and become outright ad hoc impositions of campus decision-makers' own political preferences.

Keywords: Antisemitism, Campus Speech, Democracy, Far Right, Free Speech, Higher Education, Israel-Palestine, Leftism, Liberalism

\section{Introduction}

Governments have long regulated speech deemed to be extreme, hateful, dangerous, or provocative. In the West typical limits traditionally fell under such headings as treason, sedition, public order (ordre public), blasphemy, incitement to violence (Volksverhetzung), or lèse majesté (Majestätsbeleidigung). Those older laws mostly protected government interests and majority sentiments, but sometimes also vulnerable social groups (Rohrßen, 2009). From the Middle Ages through to the American civil rights movement, battles for free speech were led by political progressives. For example, despite Karl Marx's searing critiques of individual rights regimes (Marx, 1956b), he never collapsed free speech into a purely rights-based interest in the manner of a private property right. He sought abolition of censorship as an unequivocal political advance (Marx, 1956a). ${ }^{2}$

By the 1980s, opinion on the left was nevertheless shifting. Spurred by outbreaks of racist, sexist and homophobic incidents on US university campuses, writers adopted the concept of "hate speech" to denote derogatory or threatening expression targeting vulnerable groups (Matsuda, 1993). At the same time, feminists identified within pornography (Dworkin, 1981) and within everyday speech situations (Trömel-Plötz, 1984) various paradigm instances of women's subordination. Critical theorists suggested that free speech amounts to a sheer tool for powerful interests (Heinze, 2008). The concept of "hate speech" has since spread throughout the English-speaking world and beyond (discours de la haine, discurso de odio, Hassrede). ${ }^{3}$ What emerged was a curious swap. Growing numbers of conservatives, who had traditionally been linked to censorship, started donning the libertarian mantel. Meanwhile, somewhere between left and right, opinion within mainstream liberal thought predictably divided. ${ }^{4}$ Some moderates maintained the traditional

2 See also Heinze, 2018, 31 May - 1 June 2018.

3 See, e.g., Pech, 2003; Nieuwenhuis, 2011; Josende, 2010; Noorloos, 2012; Barendt, 2007.

${ }^{4}$ For samples of opinion across the spectrum, see, e.g., Hare and Weinstein, 2009; Herz and Molnar, 2012. 
civil liberties stance (Strossen, 1990), ${ }^{5}$ whilst others endorsed some form of hate speech bans (Waldron, 2012; Thiel, 2003; Heyman, 2009).

In recent years campus activists have increasingly called for limits on speech. Reports continue to break about campaigns to deny or to retract invitations for speakers whose views are deemed threatening to vulnerable social groups. That practice commonly falls under the headings of "no-platforming" or "safe spaces". A 2016 survey indicates that large majorities of UK university students support noplatforming. ${ }^{6}$ Should such findings ring alarm bells? Certainly, not all such campaigns succeed. ${ }^{7}$ Even when they do, shall we not just say that students are still at exploratory phases in their lives and do not necessarily represent their institutions as a whole. Unfortunately, far from being sheer caprices of youth, many academic staff members equally support such campaigns. To be sure, some leftists have cast doubt on censorship. First published in 2008, Raoul Vaneigem's book Rien n'est sacré, tout peut se dire presents not free speech but silence as the servile and submissive stance under capitalist power regimes. For Vaneigem (2003), when voices can be muted the state always wins. In the current climate, however, Vaneigem (ibid.) has found little resonance among his fellow travellers. Unlike his other works, no translation has yet appeared. Judith Butler (1997), also generally associating herself with the left, has gestured towards free speech, though in cryptically hedged terms, suggesting she does accept some no-platforming yet raising doubts about where she would draw her lines (Howe, 1998). ${ }^{8}$

Debates surrounding campus speech mirror those in society more widely, but there are also noticeable differences, reflecting the distinct purposes of higher education. In this article I shall examine controversies sparked by attempts to censor speech drawing from Anglo-American higher education, where the notions of "noplatforming" and "safe spaces" have exerted considerable influence. My aim is not,

5 On the more general debates, see, e.g., Post, 1995; 2006; 2011a; 2011b; Weinstein, 1999; 2011a; 2011 b.

6 BBC Victoria Derbyshire "No Platform” Poll, ComRes, 23 April 2016, http://www.comresglobal.com/polls/bbc-victoria-derbyshire-no-platform-poll/ (retrieved 1 Aug 2018).

7 Alfie Packham, "Boris, Tatchell, Greer: were they actually no-platformed?", The Guardian, 5 May 2016, https:/www.theguardian.com/education/2016/may/05/boris-tatchell-greer-werethey-actually-no-platformed (retrieved 1 Aug 2018).

${ }^{8}$ Butler subsequently has done little to clarify her stance, taking the highly questionable concept of "free speech absolutism" as an operative target, although that notion has never seriously been embraced by free speech advocates. See J. Butler, "Limits on Free Speech?", Academe Blog, 7 Dec 2017, https://academeblog.org/2017/12/07/free-expression-or-harassment/ (retrieved 1 Aug 2018). On the error of assuming "free speech absolutism" as a meaningful point of reference, see below, text accompanying note 19 . For a re-evaluation of leftist stances, see also Gould, 2018 . 
however, to examine UK or US legal contexts per se. Controversies around provocative speakers arise in all democracies. My interest lies with identifying generally democratic principles, rather than focussing upon the details of a specific jurisdiction.

Democracies today can be viewed along a spectrum. Contrary to widespread belief, US law does not stand at a "free speech absolutist" pole, which is not and could never be a legally meaningful concept (Heinze, 2016). US law limits such speech as commercial fraud or courtroom perjury just like other democracies. What is distinctive about the US, and does place it at an extreme end of the continuum, is the Supreme Court's aversion, under principles that emerged gradually over the twentieth century, to penalising speakers solely on grounds of their dangerous or provocative viewpoints, such as unsavoury philosophies or worldviews. ${ }^{9}$ Arch-opposite democracies in that respect are Germany or France, where certain extreme or discriminatory viewpoints may be penalised as hostile to democratic norms (Pech, 2003; Nieuwenhuis, 2011; Josende, 2010). Other democracies stand somewhere between those poles.

Whatever the specifics of a given democracy's speech regulation may be, my question in this article is whether public universities ought (a) to combat intolerance by imposing tighter limits then their national laws require, as no-platformers would have us do; (b) to oppose existing limits in a drive to promote free speech; or (c) simply to follow the status quo, as universities ordinarily do with other legal rules. I shall advocate position (b), which makes it easier to speak about democracy in general. After all, options (a) and (c) would depend much more on the content and scope of censorship in each jurisdiction. I shall not, however, discuss specific means by which universities ought to challenge existing law, for example, by protesting it only in principle or by actively defying it by allowing unlawful speaking events. As a practical matter, few senior administrators, particularly within public institutions, would likely take the latter course.

I shall oppose viewpoint-selective restrictions on university speech within fully-fledged democracies, but will certainly aim to take seriously the concerns of noplatformers. Particularly important is their view that they are engaged not in exclusion but rather in inclusion, acting not against democracy, but in favour of a more egalitarian democracy. They aim to level the conversational playing field in a world in which hierarchies give the wealthy and powerful - often understood in the West as favouring an ethnically white, and particularly a male and heterosexual majority - the louder voice.

9 See, e.g., Brandenburg v. Ohio, 395 U.S. 444 (1969). See also works cited above, n. 11. 
One obstacle for the present analysis is that core concepts such as "democracy", "public discourse", "incitement", or "fighting words" have spawned lengthy and complex analyses of their own, far beyond university contexts. Those concepts cannot receive full attention within the confines of a journal-length article if the particular situation of higher education is to be examined in detail. I recognise that leaping over those issues leaves crucial matters unresolved for readers not specialised in free speech law or theory. As I have examined those matters at length in Hate Speech and Democratic Citizenship (Heinze, 2016), however, I shall not revisit them here, but hope this article's very limited points about higher education will become sufficiently clear even without the opportunity to explore all elements more generally relevant to free speech.

I shall begin in Section 2 by examining controversial far-right speakers to argue that, despite such concerns, no-platforming does not follow as a rational solution in principle, followed by Section 3 where I also argue that it fails to achieve its aims in practice. In Section 4, I argue that "safe spaces" create the same problems. Whilst originally claiming benign motives, they have recently been used in inappropriately censorious ways. I then turn to the particular example of the IsraelPalestine conflict, which has maintained a high profile on university campuses, witnessing calls for censorship on all sides. In Section 5, I criticise an attempt to block an invitation to a controversial Israeli ambassador to the UK. In Section 6, I then turn the tables, examining unjustifiable silencing of anti-Israel speech. In Section 7, I conclude by arguing that universities within fully-fledged democracies ought not simply to refrain from censorship beyond what the law requires; they must also lead the way towards challenging legally authorised censorship.

\section{Mill and Marketplaces}

In 2007 the Oxford Union debating society organised a podium about limits on free speech. Two invited speakers were David Irving, a prominent Holocaust denier, and Nick Griffin, then leader of the far-right British National Party (BNP). Protests within the Oxford community, endorsed by Members of Parliament and other public figures, sparked national headlines. For the Student Union president, such invitations risked conferring "legitimacy and credibility" on the speakers' opinions (Taylor et al., 2007). But the debating society president defended the event: "I find the views of the BNP and David Irving awful and abhorrent but my members agreed that the best way to beat extremism is through debate" (ibid.). Controversy again arose with the society's invitation in 2015 of Marine Le Pen, President of France's Front National (re-named in 2018 the Rassemblement National). One Oxford city councillor called that invitation a "stunt", claiming that local citizens "don't want this extreme right-wing racist from France given a platform here" (Henley and Ul- 
lah, 2015). In a number of continental democracies, views uttered by Irving ${ }^{10}$ as well as Front National members ${ }^{11}$ had certainly been subject to penalties as incitement to violence, incitement to hatred, or similar offenses. Such controversies are not unique to higher education; they form part of many democracies' deliberations about the scope of permissible speech. Questions nevertheless arise about the standards to which universities ought to be held. We must re-consider the mission of public higher education.

One approach is to view the university on a contractual model. Compare it, for example, to an athletic club. States may certainly fund such clubs in one or another form, particularly within primary schools or other such youth establishments; otherwise, however, we are not ordinarily required by law to pay directly into any local team. More typically, an athletic club demands dues if we individually consent to become members. Along contractual lines, the team may expel us not only for nonpayment, but also for breaches of other rules governing members' conduct, which often go further than a nation's background legal rules. They may, for example, set certain standards of conduct or attire beyond the minima required by law. On that contractual model it would seem that universities, too, could condition campus staff or student membership on adherence to speech codes above and beyond the existing legal rules. Consider a further analogy. Websites run by news agencies such as the Guardian or Independent are under no legal obligation to print readers' comments. They therefore remain free to delete comments they judge to violate house rules, including comments not otherwise illegal in law, and irrespective of whether they charge a users' fee. Readers wishing to join the Guardian or Independent "clubs", be it only for the transient purpose of posting a single comment, are held to "club rules". In the same sense, citizens are not ordinarily compelled by law to enrol in higher education. Universities might therefore be deemed justified in imposing "club rules" including internally adopted hate speech bans, and going further than the background national law requires. That contractual model, to some degree, already operates. Rules of classroom conduct to restrict disruption, for example, are generally accepted as a matter of course. A lecturer may legitimately remove a student who continually voices unsolicited remarks, even if the words uttered in other settings would not otherwise breach background legal rules.

10 "David Irving jailed for Holocaust denial", The Guardian, 20 Feb 2006, https:/www.theguardian.com/world/2006/feb/20/austria.thefarright (retrieved 1 Aug 2018).

11 See, e.g., "Chambres à gaz qualifiées de 'détail': amende confirmée pour Jean-Marie Le Pen”, Le Figaro, 1 March 2017, http://www.lefigaro.fr/flash-actu/2017/03/01/9700120170301FILWWW00179-chambre-a-gaz-qualifiees-de-detail-amende-confirmee-pour-jeanmarie-le-pen.php (retrieved 1 Aug 2018). 
Extending a contractual paradigm to the general expression of ideas nonetheless raises difficulties. Surely universities within democratic societies ought not to collapse into mere "information factories". Exchanges of ideas often take place within venues independent of classroom instruction, including campus organisations formed for activities such as social activism campaigns, religious societies, or debating societies. For the university to censor speakers on grounds of their provocative opinions serves not to pursue an academic mission but to dictate that mission a priori. Yet is that so wrong? Must the academy open its doors to any and every idea? Must it host hate preachers who advocate death to Jews and sexual minorities, or to neo-Nazis who shout "Whites only"? In the words of one anti-Le Pen demonstrator, "Fascism has only ever been beaten when good people mobilise against it. Not by inviting it to dinner" (Henley and Ullah, 2015). In the interests of quality education, why not set some threshold higher than that of the background legal system, demanding that discussion remain minimally compatible with basic values of tolerance or pluralism?

One celebrated response, perhaps quoted more frequently in recent years than ever before, comes from John Stuart Mill's famous text On Liberty (1859): "If all mankind minus one were of one opinion, and only one person were of the contrary opinion, mankind would be no more justified in silencing that one person than he, if he had the power, would be justified in silencing mankind" (Mill, 1991). Such reasoning assumes the epistemology of empiricism and natural science, widespread in mid- $19^{\text {th }}$ century British thought, whereby a seemingly irrational idea "may possibly be true". Even mathematical truth, generally accepted today as purely tautological, was thought by Mill to be inductive in nature and therefore alterable on empirical grounds. The proposition $2+2=3$ "may possibly be true" if, for example, we could one day happen upon two discrete objects paired with two others yet yielding three. ${ }^{12}$

Looking back on history since that time, Mill still seems persuasive within certain empirical domains, such as chemistry or biology laboratories. Are we convinced, however, that such an epistemology applies altogether to social and ethical realms? Do we really believe that a thesis justifying Auschwitz or the trans-Atlantic slave trade "may possibly" lay a serious claim to credibility? Do criteria of persuasion in ethics proceed in the same way as in chemistry and biology?

Mill offers a second, more plausible rationale. His better argument, particularly for higher education, is not that any and every imaginable proposition "may possibly be true", but that, even if some are false, "the clearer perception and livelier impression of truth" emerges not when it is rendered into "infallible" dogma, but

12 For a popular critique, see, e.g., Ayer, 1952: 73-75. 
through its open "collision with error" (ibid.). Essential to critical thinking is not merely knowing that something is true, but why it is true. That demand entails the trickier ability to show why rival propositions are false. Anyone who observes online debates on heated social controversies knows how difficult it can be to defend ethical positions one had assumed to be self-evident, not only against "trolls" but also against educated, articulate rivals.

In the West, for example, we widely believe that slavery two hundred years ago was ethically wrong - a view ordinarily focussed on North American plantation slavery. But was slavery also ethically wrong two thousand years ago in Europe, Africa, Asia or the Americas? If not, then when and how did it become wrong? Or was it wrong in some times and places but not in others? And where it was not wrong, was it therefore right? Are "right" and "wrong" too simplistic as final judgements? Mill's "clearer perception and livelier impression" criterion targets anyone who assumes there are straightforward answers to such questions and feels outraged at the sheer prospect of debate about them.

Mill's position is sometimes described as positing a "marketplace of ideas", a phrase he never actually uses, and which is more a product of the "roaring Twenties" in the US, adopted by such figures as Oliver Wendell Holmes or Louis Brandies - before the 1929 Wall Street crash. On that view, comparison of ideas, like comparison of products, will lead "consumers" over time to informed choices. The marketplace model admittedly forms more part of the folklore than the real theory of free speech, frequented more by pundits than by serious free speech scholars. Holmes and Brandies refer to it only in passing. Among prominent scholarly free speech advocates today, few have developed marketplace paradigms in any seriously theorised way.

Mill's model assumes what we find troubling about economic marketplaces, namely, the formal equality of all participants. The fear is that powerful interests speak with louder voices ${ }^{13}$ disadvantaging democratic deliberation in general and vulnerable groups in particular. What might worry us in that hypothetical discussion of slavery is not the topic per se but rather the balance of power among the speakers. Concerns about populism and media manipulation cast doubt on whether people will always make the best choices (Heinze, 2017b). On closer examination, however, historical evidence about intolerant ideas snowballing into devastating effects ${ }^{14}$

13 That specific concern about manipulation of democratic forums through powerful interests certainly does not begin with contemporary critical theory. It was already a recurring theme for Plato. See, e.g., Gorgias 461b-522b, in Plato, [4 $4^{\text {th }}$ century BCE] 1997, pp. 805-865. Cf., e.g., Apology, ibid., pp. 16-36.

14 See generally, e.g., Tsesis, 2002. For more recent evidence of the mobilising effects of hate speech outside established democracies, see, e.g., Tom Miles, "U.N. investigators cite Facebook 
invariably comes from non-democracies or from societies falling short of criteria to which we would hold democracies today, such as the Weimar Republic of the 1920s and early 1930s, US slave and segregationist states, or the already debilitated democracies of Rwanda or the former Yugoslav states.

Over decades, thousands of books and articles have warned about such dangerous snowballing effects of extreme speech within Western societies, yet not a single author has documented any such causal effects flowing from what I have elsewhere identified as the general sphere of public discourse within longstanding, stable, and prosperous democracies (LSPDs) (Heinze, 2016: 69-78). In Germany or France, with their strong speech controls, levels of hate speech remain comparable to levels in the US, which imposes fewer controls (ibid.: 181-194), and with greater actual violence in the US due more to lack of gun control than to free speech (Spitzer, 2012). That reference to "public discourse" is decisive. "Public discourse" does not reduce merely to anything said in a public place (Heinze, 2016: 29-30); and evidence does plausibly support the view that targeted, face-to-face harassment, particularly of a discriminatory character, can cause psychological harms (Matsuda, 1993; Trömel-Plötz, 1984). Accordingly, few of the leading free speech advocates have objected to bans on "fighting words" (except perhaps at an untenably libertarian extreme) (Heinze, 2016: 28-29). No evidence of mass violence exists, however, as to provocative speech articulated more generally within the public spheres of LSPDs. Contrary to assumptions of centuries-old democracy in the West, the LSPD model traces back no earlier than the 1960s (ibid.: 125-137). As the sociologist Ulrich Preuß (2002) has observed, the atrocities spurred by hate speech in earlier and weaker democracies followed not from speech as such, but from possibilities of rapid mass mobilisation that glaringly diminish once a state acquires LSPD character.

Those observations point to a crucial difference between, on the one hand, conventionally liberal and rights-based defences of free speech, and, on the other hand, a more distinctly democratic defence. A straightforwardly liberal or rightsbased defence must examine potential harms irrespective of venue. A distinctly democratic model, by contrast, identifies general expression of viewpoints within public discourse as politically constitutive - as the very constitution of any democratic constitution - and not merely as an indifferently exercised individual freedom (Heinze, 2016: 82-89). Under standard liberal models citizenship reduces to an administrative category, attested by birth or naturalisation certificates, passports, and the like. Under a democratic model, by contrast, the illegitimacy of excluding

role in Myanmar crisis", Reuters, 12 March 2018, https://www.reuters.com/article/us-myanmarrohingya-facebook/u-n-investigators-cite-facebook-role-in-myanmar-crisis-idUSKCN1GO2PN (retrieved 1 Aug 2018). 
citizens from public discourse solely on viewpoint-selective grounds is of a constitutional order. The citizens' prerogative of non-viewpoint-punitive participation in public discourse is unconditional. While viewpoint-selective bans do not wholly delegitimate a democracy, they do de-legitimate it pro tanto, that is, to the extent of the ban (Heinze, 2016). States commonly scoring high on democratic indicators, ${ }^{15}$ such as Iceland or Norway, do lose legitimacy to the extent they maintain such bans, but remain top-performers inasmuch as their freedoms of expression continue overall to enjoy the strongest levels of protection. To be sure, appeals to democracy arise on both sides of the free speech debates. Elsewhere I have nevertheless argued that theories of militant democracy and equal citizenship invoked in support of bans nevertheless fail to satisfy essential criteria of political legitimacy (ibid.: 129-137, 153-162).

Many democracies, of course, are not LSPDs. On leading indicators, for example, the United States has for years weighed in only as borderline. ${ }^{16}$ Younger democracies today face particularly great obstacles. Accordingly, viewpoint-selective limits on speech may serve at best as security measures, and even then only with adequate safeguards, in view of states' tendencies to exaggerate security concerns (ibid.: 78-81). In no sense, however, can a speech ban be called an inherently democratising measure according to the view that a bit less democracy may sometimes help to secure more and better democracy. ${ }^{17} \mathrm{~A}$ ban serving to eliminate speech from public discourse solely on viewpoint-selective grounds is always inherently anti-democratic, even when adopted on legitimate security grounds.

Unlike public institutions, privately funded universities might in theory be construed under a more strongly contractual model. A body such as a non-taxpayerfunded theological seminary might, for example, legitimately expel a student who openly professes atheism on grounds of fundamental unsuitability for the institution's core mission. For the most part, however, actual practice reveals a different picture. Private universities are widespread, for example, in the US. Not falling within agencies of government, nor are they formally bound by the First Amendment, which protects individuals only from censorship by the state (although even there, partial state funding may complicate matters). In their declared policies and conduct, those private universities have tended to embrace First Amendment principles. In any event, as my focus here is on state-sponsored institutions, I shall not pursue that matter here.

15 See, e.g., EIU, Democracy index 2016 (London: The Economist, 2017).

16 The United States perennially fails to rank even among the top twenty states on democratic indicators as assessed annually by the Economist Intelligence Unit (EIU).

${ }^{17}$ Cf., e.g, Gündüz v. Turkey, ECHR, no. 35071/97, judgment of 4 December 2003, para. 40; cf. Erbakan v. Turkey, ECHR, no. 59405/00, judgment of 6 July 2006, para. 56. 


\section{Principles and Pragmatics}

No-platformers object, then, that their aim is not to deny free speech, but the opposite, to ensure that those least represented will not be crowded out of the public sphere. "Universities should prioritise the voices of the most vulnerable on their campuses", according to one no-platforming appeal, "not invite speakers who seek to further marginalise them." ${ }^{18}$ Given ongoing problems of discrimination, figures like Irving, Griffin and Le Pen serve, on that view, to perpetuate $u n$-free speech by reinforcing existing inequalities. The case against those speakers is consequentialist: if such figures are denied a platform, then their influence will diminish, even if only to a small degree. Is that claim credible? One Oxford student defended Le Pen's invitation in a classically liberal, Millian spirit: "This protest is ironic and counterproductive. Ironic because stifling debate is the essence of fascism, and counterproductive because the way to challenge these ideas is by confronting them in open and public debate" (Henley and Ullah, 2015). Indeed, leaving aside questions of political philosophy, we can track that actual counter-productivity even further. Within pluralist democracies attempts at censoring high-profile extremists to limit their notoriety commonly produce the opposite effect. In 2017 unrest broke out when controversial speakers were invited to speak at a "free speech week" held by conservative students at the University of California, Berkeley. Heated demonstrations took place against the right-wing commentator Milo Yiannopoulos. Prior to the protests Yiannopoulos, familiar enough among those attentive to media trends, remained unknown to much of the public. Pre-publication sales of his book Dangerous had been temperate. The censorship campaign turned him into an overnight sensation. Far from reducing Yiannopoulos's influence, it immediately and vastly enlarged it. Orders for his book skyrocketed. ${ }^{19}$ If the no-platformers silenced Yiannopoulos at Berkeley, ${ }^{20}$ it was only to boost his presence in the rest of the world. ${ }^{21}$

18 "Cardiff University: Do not host Germaine Greer", online petition at change.org, https:// www.change.org/p/cardiff-university-do-not-host-germaine-greer (retrieved 1 Aug 2018).

19 See Hillel Italie, "UC Berkeley protests send pre-sales of Milo Yiannopoulos's new book soaring", The Conversation, 3 Feb 2017, https://www.independent.co.uk/news/world/americas/uc-berkeley-protests-milo-yiannopoulos-new-book-pre-sales-rise-soar-alt-right-cancelledtalk-a7561356.html (retrieved 1 Aug 2018). The book publication ultimately took another course in view of subsequent events.

${ }^{20}$ Katy Steinmetz, "Milo Yiannopoulos Finally Spoke at Berkeley. But the Protesters Were Louder", Time.com, 25 Sept 2017, http://time.com/4955245/milo-yiannopoulos-berkeley-freespeech-week/ (retrieved 1 Aug 2018).

21 Yiannopoulos did subsequently reduce his public profile, but only due to a slur damaging him within his own political base. See, e.g., Patrick Strudwick, "Milo Yiannopoulos Calls Abuse Victims 'Whinging, Selfish Brats' In A Newly Emerged Video", BuzzFeed, 11 March 2017, https:// www.buzzfeed.com/patrickstrudwick/milo-yiannopoulos-described-sexual-abuse-victims-aswhinging?utm_term=.qyZKR0jk2\#.onMX93Y7d (retrieved 1 Aug 2018). 
No-platformers could well concede that boomerang effect as a price to be paid when we stand up for principle, and might suggest a chain of causation running in the opposite direction. One anti-Le Pen demonstrator regretted that the politician could "now go back to France and say she has been invited to speak at Oxford University. That is the kind of legitimacy that is allowing her and her abhorrent party to become acceptable" (ibid.). As a preliminary matter, it is important to note that the term "legitimacy" poses problems because it tends to be used in various senses. Under that colloquial usage it simply means something like "acceptance" or "recognition". Such usage differs from the stricter, deontological sense of denoting elements necessary for law to lay a claim of obedience (Heinze, 2017a: 636-639). That worry about legitimacy in the everyday sense of "acceptance" has no obvious meaning except, in consequentialist terms, as a fear of enhanced popular support; yet Le Pen's polling figures had already been relatively strong before the Oxford debate, ${ }^{22}$ with not a single subsequent opinion poll suggesting any leap in support at all. We can certainly rule out any assumption that the mainstream French media, scarcely in the habit of cowtowing to the far right during that election campaign, would somehow have covered the Oxford event less critically than the leading British media had covered it or less critically than they were covering Le Pen on French soil. Once again, reality ran contrary to the no-platformers' predictions. The French coverage proved far more scathing than the British. Headlines showed little interest in Le Pen's message, instead relishing the jeers of "Nazi scum" (racaille nazie) hurled at her on the evening of the debate ${ }^{23}$ - hardly a discouraging outcome if we're worried about farright demagogues using prestigious university venues to boost their public profiles.

22 "Marine Le Pen en tête en 2017, des sondages à lire avec prudence", Matthieu Goar, Le Monde, 30 Jan 2015, http://www.lemonde.fr/politique/article/2015/01/30/marine-le-pen-en-teteen-2017-des-sondages-a-lire-avec-prudence_4567091_823448.html (retrieved 1 Aug 2018); "SONDAGE. Sarkozy chute, surtout à droite", L'Obs (formerly Le Nouvel Observateur), 22 Feb 2015, https://www.nouvelobs.com/politique/20150222.OBS3116/sondage-sarkozy-chutesurtout-a-droite.html (retrieved 1 Aug 2018).

23 “Marine Le Pen chahutée lors d'un déplacement à Oxford", BFMTV, 6 Feb 2015, http://www. bfmtv.com/politique/le-pen-chahutee-a-oxford-861946.html (retrieved 1 Aug 2018); “"Racaille nazie': Marine Le Pen accueillie par des huées à Oxford", L'Obs, 7 Feb 2015, https://www. nouvelobs.com/politique/20150207.OBS1940/racaille-nazie-marine-le-pen-accueillie-par-deshuees-a-oxford.html (retrieved 1 Aug 2018); "Marine Le Pen à Oxford: des centaines de manifestants contre la 'racaille nazie", Huffington Post.fr, 6 Feb 2015, https://www.huffingtonpost. fr/2015/02/06/marine-le-pen-oxford-centaines-manifestants-racaille-nazie_n_6629132.html (retrieved 1 Aug 2018); “"Racaille nazie': Marine Le Pen huée par des étudiants à Oxford”, Europe 1, 6 Feb 2015, http://www.europe1.fr/politique/racaille-nazie-accueil-houleux-pour-marine-le-pena-oxford-2365779 (retrieved 1 Aug 2018); "Oxford: Marine Le Pen se fait traiter de 'racaille nazie' par des manifestants", Atlantico, 6 Feb 2015, http://www.atlantico.fr/pepites/oxford-marinepen-se-fait-traiter-racaille-nazie-manifestants-1993188.html (retrieved 1 Aug 2018). 
Any suggestion that the event lent increased credibility to the Front National illustrates what I have elsewhere identified as the tactic of rhetorical consequentialism widespread among advocates of speech bans, who insist on empirical links between speech within the public discourse of LSPDs and resulting social harms, yet without citing empirical evidence. Pseudo-empirical claims are adduced in the sense that pro-ban arguments take the verbal form of merely asserting some empirical link between extremist speech and social harm (e.g., "We must stop the speech lest it lead to violence"), with actual evidence remaining either undecided or indeed often, as in the Yiannopoulos and Le Pen instances, suggesting the opposite of what the no-platformers predict (Heinze, 2016).

Some no-platformers unsurprisingly abandon consequentialist theses in favour of deontological ones, that is, standpoints rooted not in empirical claims about harmful effects, but in ethical principle. ${ }^{24}$ Some no-platformers might well concede that they cannot demonstrate clear material causation between hateful public discourse within LSPDs and harmful social effects. They nonetheless oppose on principle the promotion of speakers who propagate anti-pluralist ideas. Yet that position only leads us back to square one. We must again enquire into the purposes of higher education. We might certainly distinguish between, on the one hand, passively admitting an individual's free speech and, on the other hand, materially facilitating that speech. "This isn't about freedom of speech", claimed the organiser of Oxford's anti-Le Pen protests. "She has the right to express her views; no one is trying to silence her. But that doesn't mean we have to invite her here to give an hourlong talk and bring her bigoted, divisive politics into our community" (Henley and Ullah, 2015). That view again raises the question of whether universities ought to crack down beyond the requirements of the background legal regime. Le Pen's free speech indeed does not entail any university's affirmative duty to host her views. However, expressive prerogatives concern not merely the speakers' freedoms but also those of campus members wishing to hear and to debate. Several months after Le Pen's address a further Oxford debate was held to examine the limits of speech. One British-Asian student in the audience asked on what grounds other university members could legitimately deprive her of the opportunity to face and to interrogate intolerant speakers in person, as part of the university's commitment to critical thought. ${ }^{25}$ No-platformers, in other words, even if we assume that they represent head-count majorities within disempowered groups, in no way represent some political idea inherently constitutive of those groups.

24 For a strong deontological (or “dignitarian”) theory, see Heyman, 2009.

25 “Should universities practice no-platforming?", 19 Nov 2015, recording available at http:// freespeechdebate.com/media/to-speak-or-not-to-speak-should-universities-practice-no-platforming/ (the intervention mentioned here draws from my personal attendance). 
Joan Wallach Scott observes, moreover, the irony, particularly within educational contexts, of renouncing channels of intellectual challenge as a response to the anti-intellectualism characteristic of resurgent populisms. Values of "knowledge, democracy, and the common good", she argues, "must be reasserted in defense of the university and against the anti-intellectualism of the Trump administration" (Scott, 2017). ${ }^{26}$ Cass Sunstein (2003b) opposes no-platforming because viewpointselective censorship within higher education (as well as in other social contexts) promotes "group polarization" and "enclave deliberation". Those phenomena occur when like-minded people, such as members of a given social group or movement, focus on internal deliberation, leading them towards ever more extreme positions. In other words, after discussions with their peers, they end up accepting or thinking a more extreme version of what they thought before they started to talk (Sunstein, 2003b: 11). ${ }^{27}$

\section{Safe Spaces and Power Hierarchies}

Like "no-platforming", the creation of "safe spaces" has recently caught headlines. In 2015 New York Times journalist Judith Shulevitz described a facility at Brown University in Rhode Island "intended to give people who might find comments 'troubling' or 'triggering' a place to recuperate". The room "was equipped with cookies, coloring books, bubbles, Play-Doh, calming music, pillows, blankets and a video of frolicking puppies". In themselves such spaces are harmless and can meet a valid concern, as Shulevitz points out, by supporting vulnerable students such as rape victims. ${ }^{28}$ Shulevitz probed the Brown facility not because a room had been specially reserved for vulnerable students but because it had been set up in response to a controversial event. The libertarian Wendy McElroy had been invited to speak in view of her controversial rejection of theories of "rape culture" current in some feminist circles. But why should we worry about students gathering to blow bubbles or draw in colouring books? We may find it infantilising, but that is a concern about psychological preferences, not about expressive freedoms. Safe spaces of that type clearly pass any serious free speech criteria in the sense that students must retain the prerogative to visit such facilities as an exercise of their own freedoms of expression and association.

That originally innocuous policy has, however, come to signify something more alarming. Instead of designating a discrete meeting place within the campus,

${ }^{26}$ I am grateful to Neve Gordon for bringing this position to my attention.

27 I am grateful to Kristian Ekeli for drawing the links between my points here and Sunstein's.

28 Judith Shulevitz, "In College and Hiding from Scary Ideas", New York Times, 21 March 2015, https://www.nytimes.com/2015/03/22/opinion/sunday/judith-shulevitz-hiding-from-scary-ideas.html (retrieved 1 Aug 2018). 
designated speaking venues themselves have been policed as "safe spaces". In 2017 King's College London hired paid marshals assigning them powers to evict anyone appearing to breach campus speech codes. ${ }^{29}$ That role confers discretion to decide what counts as a breach, a question often perplexing trained jurists. Safe spaces in the original sense of secluded meeting rooms may pose no threat to others' free expression, but when the policy becomes a dragnet targeted not only at speakers but even at audience participants, that role entirely changes. "Safe space" comes to mean "censored space".

Particularly pernicious is the abuse of the concept of safety. University campuses within Western societies are often large, open environments. No such space can be rendered wholly free of danger, but they generally maintain security infrastructures. In the eyes of countless people in the world who have confronted mass violence, such "campuses would seem celestially serene. It degrades the meaning of 'unsafe' to designate as such a controversial speaking event conducted in a protected campus environment. To label a controversial discussion a safety threat is the oldest trick in the censor's bag" (Heinze, 2017c). Campus members facing actual safety threats are ordinarily free to contact campus staff, security, or local police. If they still feel unsupported, then that is the appropriate target of any campaign, as opposed to the ideas of a controversial speaker. ${ }^{30}$

Akin to such safety claims are inflated assumptions about power differentials. As already mentioned, no-platformers commonly argue that their aim is not to foil equal speech opportunities but to promote them, denying platforms to those who advocate unduly powerful positions in order to support marginalised voices. Prominent examples have included attempts to no-platform speakers expressing reservation about transgender rights. Germaine Greer and Peter Tatchell, long associated with the political left, nevertheless became targets of such campaigns. Greer had expressed doubts about transgender identities ${ }^{31}$ and Tatchell had in turn endorsed her prerogative to do so. ${ }^{32}$ No-platformers understandably view transgenders among the most disempowered in society. Here too, the problem lies not with the core premise

${ }^{29}$ Eleanor Rose, "King's College London deploys 'Safe Space Marshals' to ensure students 'don't have their feelings hurt' at talks”, Evening Standard, 27 Oct 2017, https://www.standard. co.uk/news/london/kings-college-slammed-for-patronising-and-problematic-safe-space-marshals-paid-12-an-hour-to-police-a3669151.html (retrieved 1 Aug 2018).

${ }^{30}$ Cf. Feiner v. New York, 240 U.S. 315, 326 - 27 (1951) (Black, J., dissenting).

31 See online petition, https://www.change.org/p/cardiff-university-do-not-host-germaine-greer (retrieved 1 Aug 2018).

${ }^{32}$ See, e.g., Tracy McVeigh, "Peter Tatchell: snubbed by students for free speech stance", The Guardian, 13 Feb 2016, https:/www.theguardian.com/uk-news/2016/feb/13/peter-tatchell-snubbed-students-free-speech-veteran-gay-rights-activist (retrieved 1 Aug 2018). 
that power differentials exist, namely, that great gaps of power and wealth do indeed inhibit equal participation, but rather with the supposed conclusion - contradicted, as we have seen, in the cases of Le Pen, Yiannopoulos, and others - that censorship campaigns operate to narrow those gaps. ${ }^{33}$

No-platforming is commonly presented as if it applies only under rare circumstances. It is nearly impossible, however, to name any serious social, economic, or political problem to which problems of power hierarchies would not apply. In a debate about market regulation, for example, we would not merely have to disagree with, but would altogether have to censor advocates of free markets if we are to deny a platform to those whose politics may promote powerful interests at the expense of the marginalised. In a debate about education budgets we would have to censor those whose spending would entail cuts to disadvantaged pupils. In a debate about health care we would have to censor those whose plans inadequately deliver to persons most in need. In a debate about abortion rights we would have to censor those whose opposition would disadvantage women. We can multiply such examples endlessly. In each case any "debate" would be no such thing, as it could only admit one side.

The point of that apparent "slippery slope" argument is not that no-platformers aim for Stalinist levels of censorship, but only to suggest how arbitrary such campaigns become once they cease to follow any consistent principle. The only alternative to such massive censorship ends up being ad hoc decisions such that speaking events fall subject to the serendipity of whichever committee happens to be tasked with deciding for the campus community what really counts as social exclusion. Questions as to who represents the empowering and the disempowering positions are, on some issues, precisely what needs to be debated. Economic liberals believe, for example, that free markets create the best prospects for elevating the powerless. A sceptic might find that view to be far more responsible for worldwide disempowerment than the views of Griffin or Yiannopoulos. But that debate cannot take place - not as a debate - if one side is barred ab initio on grounds of representing hierarchical privilege.

\section{Censorship of Pro-Israel Views}

The seeming "slippery slope" claim is not that an ethical stance must remain free of internal contradiction in order to gain credibility, implemented either in its entirety or not at all. No such aspiration is achievable for any complex social controversy.

${ }^{33}$ Cf., e.g., Alex Sharpe, "Let Germaine Greer speak. It's the fastest way to discredit her", The New Statesman, 27 Oct 2015, https:/www.newstatesman.com/politics/feminism/2015/10/letgermaine-greer-speak-its-fastest-way-discredit-her (retrieved 1 Aug 2018). 
The problem is that a thoroughgoing incoherence emerges not merely at the periphery but at the very core of the concept of power inequality, once it translates into concrete choices about who and what ought and ought not to appear on campuses. To remain intellectually coherent, no-platforming would have to sweep broadly, censoring endless viewpoints; alternatively, to respect free speech, keeping its applications rare and exceptional, it necessarily becomes $a d$ hoc, subject to the purely personal preferences of whoever has a final say about campus events (Heinze, 2009).

Again, it is tempting to dismiss such incongruities as whimsical campus politics led by inexperienced students. Their more seasoned instructors, however, also embrace such campaigns. In 2017 two student societies at London's School of Oriental and African Studies (SOAS), the Jewish Society and the United Nations Society, invited as guest speaker the Israeli ambassador Mark Regev. It was a controversial choice given Regev's position as government spokesman during the 2014 Gaza conflict, which subsequently witnessed Israel subjected to extensive criticism on both its military and civilian policies, ${ }^{34}$ and more generally on the state's founding and history. The invitation sparked nationwide, indeed international mobilisation. As reported in The Guardian, over a hundred academics both within and beyond SOAS, joined by a number of student societies, requested that the university's Director Lady Valerie Amos cancel the event (Weale, 2017). ${ }^{35}$ No campus censorship campaign in Britain has compared in terms of the speed and scope of that highly organised response.

One of the no-platformers' rationales was that "the format of this meeting does not permit Regev's case, such as it is, to be subjected to any scrutiny". ${ }^{36}$ To avoid the impression of censoring solely to promote their own politics, the no-platformers' surface appeal here is to a prima facie legitimate principle: academic events ought to follow criteria of scholarly rigour. Countless speaking events take place every day in universities, however, allowing speakers to make all and sundry claims in areas of ethics, politics, and social science, but with no such mechanisms for quality

${ }^{34}$ See, e.g., Annual report of the United Nations High Commissioner for Human Rights and reports of the Office of the High Commissioner and the Secretary-General: Human rights situation in Palestine and other occupied Arab territories ("Ensuring accountability and justice for all violations of international law in the Occupied Palestinian Territory, including East Jerusalem: comprehensive review on the status of recommendations addressed to all parties since 2009"), UN Human Rights Council, 12 June 2017, UN doc. A/HRC/35/19.

35 A total of four signed letters were published, and as of this writing still appear, on the Facebook site of the group Free Speech on Israel (FSOI), posted by group member Naomi Wimborne-Idrissi on 23 April 2017, https://www.facebook.com/groups/FreeSpeechonIsrael/permalink/1877279302493531/ (retrieved 1 Aug 2018).

${ }^{36}$ Letter by 53 non-SOAS UK academics, ibid. (emphasis added) (also quoted in Weale, 2017). 
control, nor indeed any obvious way in which criteria could even be agreed upon. The usual avenue of scrutiny consists in questions and comments posed by persons in attendance - indeed sometimes for only brief time frames.

That claim can have only one possible meaning, namely, that "the format of [Regev's] meeting" had somehow been engineered to preclude such genuine exchanges of questions and comments. The event, on that view, would merely stage a scripted recitation, followed either by no questions at all, or by planted questions to be posed by pro-Israeli audience members, or by only fleeting opportunities extended to participants at large for genuinely critical questions. A statement posted online by the SOAS Students Union makes that assumption clear: "We stand with the SOAS community in expressing our concern at Mark Regev's presence on campus, and in rejecting the idea that our spaces of learning should serve as avenues for officials to put forward state propaganda." 37

Two problems arise. First, government officials, both domestic and foreign, including from highly-criticised states, are hardly strangers to university campuses. Other foreign figures, too, have at times been protested, ${ }^{38}$ but never on any such massive and inter-collegiate scale. One might indeed argue that a central mission of higher education is learning how to expose propaganda instead of censoring it and thereby leaving it unexamined. Organisers of such events surely understand that government or other such representatives, charged to explain official policies, are, in that sense, invited for the very purpose of airing "propaganda". The former Pakistani dictator Pervez Musharraf ${ }^{39}$ was invited to talk at SOAS in 2012 with no protest reported. SOAS Radio indeed aired the event, ${ }^{40}$ without any apparent staff or student opposition. Somewhat puzzling, then, is the apparent suggestion that Israel advances its interests differently, "putting forward state propaganda" as if other invited officials, who prompt no such resistance, somehow do not do so, or not in

37 “Students' Union statement on upcoming society event hosting Mark Regev", SOAS Students' Union, Facebook site, https:/www.facebook.com/soas.su/posts/1653350118013047 (retrieved 1 Aug 2018) (emphasis added) (also quoted in Weale, 2017). The same accusation of propaganda is included in the letter from 32 student societies at SOAS.

38 See, e.g., Helene Cooper, “Ahmadinejad, at Columbia, Parries and Puzzles”, New York Times, 25 Sept 2007, https://www.nytimes.com/2007/09/25/world/middleeast/25iran.html (retrieved 1 Aug 2018); "Protest Saudi Crown Prince Mohammed Bin Salman at MIT", Massachusetts Peace Action, 23 Feb 2018, http://masspeaceaction.org/protest-saudi-mit/ (retrieved 1 Aug 2018).

39 See, e.g., Human Rights Watch, "Pakistan: Hold Musharraf Accountable for Abuses", 23 March 2013, https:/www.hrw.org/news/2013/03/23/pakistan-hold-musharraf-accountable-abuses (retrieved 1 Aug 2018).

40 "Pervez Musharraf: Pakistan, Politics, and the War on Terror", SOAS Radio, 16 Feb 2012, https:// soasradio.org/speech/episodes/pervez-musharraf-pakistan-politics-and-war-terror (retrieved 1 Aug 2018). 
the same way. Second, since beginning his UK placement, Regev had regularly visited universities throughout Britain. He followed the same "format" at SOAS that he followed at other campuses. Persons attending were generally members of the academic community, attendance having been checked by university monitors at the door. Each session, albeit usually held in the evenings and therefore subject to building closure rules, was normally scheduled for well over an hour. During each visit, instead of presenting any opening statement at all, Regev devoted the session entirely to audience interventions. Having chaired such sessions at two University of London colleges, SOAS and Queen Mary, I have always informed the Israeli embassy from the outset that I had no interest in recitations from prepared scripts and would not welcome them. The embassy agreed in each case, confirming that it had not at any point been the Ambassador's practice to deliver one. To my knowledge, Regev's appearances chaired by others have been conducted the same way.

A small minority of attendees at each event indeed voiced support for Israel. Overwhelmingly, however, the questions posed were critical, often stridently so. Attendees above all raised concerns, including some with which I personally launched each session, about everyday living conditions in the Occupied Territories, daily militarisation, use of force, access to resources and services, imposed checkpoints and identity controls, expanding settlements, US military and financial backing, anti-Palestinian and anti-Arab racism, the legitimacy of Israel's founding and ongoing existence, and compliance with international law. Any groups or individuals wishing to voice opposition to the event were, moreover, free to do so in the form of organised protest. The SOAS no-platformers made no reference to those existing campus precedents - a notable omission given their public claim that Regev's remarks would be delivered without scrutiny. Each event was structured to consist of nothing but interactive scrutiny throughout the entire session.

An anonymous group identifying as "eighteen Palestinian students at Soas" wrote to Lady Amos maintaining, "The environment that Mr Regev would create on our campus for the event is unsafe for us as Palestinian students, many of whom have suffered directly at the hands of the Israeli security services". ${ }^{41}$ Such a statement can have no meaning except insofar as it presupposes a more general ethical position, namely, that representatives of regimes whose victims study in the West ought to be denied platforms. Yet Western universities do host staff and students from such regimes, with no such degree of mobilised national and even international opposition from persons purporting to oppose repressive regimes.

A further complaint decried "the inability of students and staff - in particular Palestinian students - to participate openly in the debate, because of possible repercus-

${ }^{41}$ Letter from 18 Palestinian students (also quoted in Weale, 2017) (emphasis added). 
sions on their ability to enter Israel/Palestine". ${ }^{42}$ A similar claim condemned "what a recent UN report refers to as the Israeli 'apartheid regime"" ${ }^{43}$ maintaining: "We fear that if this provocative event proceeds as planned, it will cause substantial distress and harm to many of our students and staff who are, have been or will be affected by [Israeli] actions." ${ }^{44}$ Once again, it remains hard to fathom how an Israeli official poses that risk more than officials from a good number of other states whose representatives are not, or are only barely, protested. Once again, that is not simply a "slippery slope" or "whataboutery" claim along the lines that a principle must be applied either with exhaustive consistency or not at all. Rather, the lack of any comparable mobilisation against persons representing repressive regimes suggests it cannot seriously be free speech at all with which the opponents of Regev's invitation are seriously concerned. One might well entertain the thesis that full free speech will be allowed only to representatives of regimes which themselves fully allow it. If that principle is to be adopted, however, then university censors will be busy indeed. Given a ranking of 45 in the 2018 World Press Freedom Index even invitations to US diplomats would not be self-evidently admissible, ${ }^{45}$ particularly given that the US can scarcely recite security threats comparable to Israel's. For many years leading up to the SOAS event (and continuing still), events critical of Israel have been campus mainstays, including yearly Israel Apartheid Week events involving mock checkpoint displays, and "Die-Ins", where participants or visitors could just as easily be photographed, if that is the concern, as at Regev's event. It is unclear how Regev's visit poses dangers that such campus members are not already willing to incur. Visiting students and Western academic life generally are monitored on a vastly greater scale by other regimes, including far more intrusive censorship pressures, most glaringly China, ${ }^{46}$

42 Students' Union statement (also quoted in Weale, 2017).

${ }^{43}$ Letter from over 100 SOAS staff. On doubts surrounding UN authority in its approach to Israel, see, e.g., Freedman, 2013.

44 Letter from over 100 SOAS staff (also quoted in Weale, 2017).

45 Reporters without Borders, 2018 World Press Freedom Index (n.d.), https://rsf.org/en/ranking (retrieved 1 Aug 2018); “RSF Index 2018: Hatred of journalism threatens democracies", https:// rsf.org/en/rsf-index-2018-hatred-journalism-threatens-democracies (retrieved 1 Aug 2018).

46 See, e.g., Bethany Allen-Ebrahimian, "The Chinese Communist Party Is Setting Up Cells at Universities Across America", Foreign Policy, 18 April 2018, http://foreignpolicy. com/2018/04/18/the-chinese-communist-party-is-setting-up-cells-at-universities-across-america-china-students-beijing-surveillance/ (retrieved 1 Aug 2018); Tao Zhang, "How can scholars tackle the rise of Chinese censorship in the West?", Times Higher Education, 18 Jan 2018, https:/www.timeshighereducation.com/features/how-can-scholars-tackle-rise-chinese-censorship-west (retrieved 1 Aug 2018); Anders Corr, "Chinese Informants in the Classroom: Pedagogical Strategies”, Forbes, 28 June 2017, https://www.forbes.com/sites/anderscorr/2017/06/28/ chinese-informants-in-the-classroom-pedagogical-strategies/\#52f981eb12da (retrieved $1 \mathrm{Aug}$ 2018). 
as well as Turkey. ${ }^{47}$ Only the most conspiratorial view of Israel can rank its interventions at any such level, yet we witness no such coordinated mobilisation in response, again suggesting the activists simply wish to censor a viewpoint they oppose.

The complaint continued: "The event could further cause serious tension on campus and result in a charged atmosphere that will be detrimental to the wellbeing of all faculty, staff and students." ${ }^{48}$ The historical echoes of such a claim are notable. The authors attribute to a Jewish entity the power of a government mandarin who, merely by spending an hour or two on campus, can inflict "detriment" upon the "wellbeing" of "all faculty, staff and students". Yet again, no government official visiting from any other nation appears to have been depicted through that kind of discourse with such highly organised and far-reaching assent among professional academics (Benz, 2005). ${ }^{49}$ One might argue that such rhetoric ought not to be read literally, that it merely forms part of the heat of political debate. But there lies the strongest argument against no-platforming, namely, that such debate ought therefore to take place as opposed to such claims being made to foreclose it. Lady Amos, a human rights expert in her own right, and a specialist in problems of discrimination, ultimately authorised Regev to appear (Weale, 2017).

\section{Censorship of Anti-Israel Views}

Censorship campaigns are not waged only against pro-Israel positions. In 2015 a major inter-disciplinary conference was scheduled at the University of Southampton entitled "International Law and the State of Israel: Legitimacy, Responsibility and Exceptionalism", ${ }^{50}$ described by the organisers as "unique because it concerns the legitimacy in international law of the Jewish state of Israel" (Siddique, 2015). The Zionist Federation of Great Britain gathered over 6000 signatures protesting that the conference would "legitimize the harmful message that Israel's very existence is up for debate". ${ }^{11}$ The petition hardly continued on a persuasive note: "This

47 See, e.g., Frank Hermans, "Turkse studenten durven niet naar Nederland uit angst voor represailles", Algemene Dagblad, 4 Sept 2017, https://www.ad.nl/binnenland/turkse-studenten-durven-niet-naar-nederland-uit-angst-voor-represailles a638b18d/ (retrieved 1 Aug 2018).

48 Letter from over 100 SOAS staff (also quoted in Weale, 2017).

49 On re-appropriation of antisemitic stereotypes within anti-Israel discourses see also regularly updated reports in The Guardian at https://www.theguardian.com/news/antisemitism and The Independent at https:/www.independent.co.uk/topic/labour-antisemitism-row.

50 See "International Law and the State of Israel: Legitimacy, Responsibility and Exceptionalism - Conference Themes" at https://www.southampton.ac.uk/israelpalestinelaw/call_for_papers.page (retrieved 1 Aug 2018).

51 “Cancel Your Upcoming Anti-Israel Conference", online petition at change.org, https://www. change.org/p/university-of-southampton-cancel-your-upcoming-anti-israel-conference (retrieved 1 Aug 2018). 
isn't about academic freedom. We welcome genuine and open discussion about the issues surrounding the Israeli-Palestinian conflict. But how can you discuss anything with people who don't even recognise your right to have a voice?" 52 The answer to that question is of course that no such discussion is possible, mirroring the "lack of scrutiny" point lanced to block Regev's visit. A Zionist Federation spokesman insisted that the event would fail to offer "a valid academic discussion" (ibid.), there too echoing the "scrutiny" and "propaganda" claims employed to cancel Regev's appearance. In fact, both events were scheduled to be open to all members of their respective campus communities. Reciting concerns about its ability to provide adequate security in the face of possibly large-scale disruptions, Southampton University cancelled the conference. "It's clear that security is a fig-leaf to stop the conference", one organiser argued. "It's ridiculous to say [the university] cannot ensure the safety of the participants" (ibid.). Here too, a safety rationale supplies a pretext for censorship. The Zionist Federation statement further claims, "At a time when antisemitism is on the rise throughout Europe, it is a disgrace that a respectable university would provide a platform to legitimise the idea that the Jewish homeland - of all the countries in the world - is somehow abnormal. Israel is presumed guilty of the crime of existing, while no other state is being put on trial in this way. Southampton University - this isn't a conference. It's a kangaroo court. Don't let it go ahead." 53

A counter-petition retorted, "It is standing principle and recognised practice that academic conference organisers have the right to choose those speakers and topics they feel would best address the purposes of the conference, without these being dictated to them by outside parties." 54 That internationally acclaimed response was - surprisingly? unsurprisingly? - signed by several academics who publicly supported the cancellation of Regev's event. Despite the statement's even-handed phrasing, then, those supporters patently did not believe that all "academic conference organisers have the right to choose those speakers and topics they feel would best address the purposes of the conference". That group's thinking might perhaps be explained as a kind of "whataboutery" - "No free speech for you if we don't get it too". It is questionable, however, whether higher education is served by reducing free speech to a bargaining chip. Once again, if universities were to admit speakers only on the condition of "equal time" for those with contrasting views, their censors would be busy indeed. There are certainly viewpoint-neutral ways in which

\section{Ibid.}

${ }^{53}$ See petition, https://www.change.org/p/university-of-southampton-cancel-your-upcominganti-israel-conference (retrieved 1 Aug 2018).

54 "Statement in support of the University of Southampton", http://freespeechsouthampton. blogspot.co.uk/2015/03/pressure-is-being-exerted-on-university.html (retrieved 1 Aug 2018). 
a playing field can be levelled, for example, by according equal time to all sides in a debating event. Indeed, there are even legitimate viewpoint-selective ways of levelling the field insofar as they do not entail censorship, such as creating special courses, journals, or media sites devoted to matters of race, colonialism, globalisation, sexuality, identity, economic oppression, and the like. I have thus far sought to suggest, however, that one postulate is never legitimate within a fully-fledged democracy outside a formally declared and judicially reviewable state of emergency (Heinze, 2016: 70), namely, to assume that either a democracy or its institutions of higher education can be enhanced by censoring a speaker solely on viewpoint-selective grounds. Although no signed statement was publicly released to endorse Regev, the converse scenario also seems likely, namely, that Regev supporters had opposed the Southampton conference - which would be an equally untenable position.

To distinguish pro-Israel from anti-Israel censorship, it has been suggested that the former has been initiated within academic communities, whilst the latter received impulses from "outside parties" (Gould, 2018), such as the Zionist Federation. That concern becomes relevant, however, only once we do assume a posture of censorship, within which we would then have to decide who ought and ought not to be censored. From an anti-censorship standpoint, such distinctions between the university's "inside" and its "outside" - which in many instances, well beyond the problem of Israel, would be murky at best - become irrelevant. Universities today avidly promote polices of interaction with society at large, including innumerable sources of outside funding. Across the political spectrum scholars use higher education institutions as springboards for disseminating their political standpoints within the wider world. Anti-Israel campaigners have certainly galvanized universities to become political actors on the "outside", ${ }^{55}$ far beyond any purely educational mission as conventionally understood. One prominent critic of Israel, Naomi Wimborne-Idrissi, ${ }^{56}$ holding at the time no appointment at any academic institution, coordinated the social media campaign against Regev (Weale, 2017) through an outside organisation.

Taken together, the SOAS and Southampton controversies reveal bad faith on both sides - free speech claimed for one's own views, but no-platforming for the opposite side. Whatever no-platforming may represent in principle, in practice it invariably means censoring one's rivals while admitting free speech for one's allies. Commitment only to the speech we like is, of course, no commitment at all. In subsequent conferences after the Southampton controversy, I condemned the 2015 can-

${ }^{55}$ See, e.g., the $B D S$ website at https://bdsmovement.net/academic-boycott (retrieved 1 Aug 2018).

${ }^{56}$ See, e.g., openDemocracy, 14 March 2018, https://www.opendemocracy.net/naomi-wimborne-idrissi/another-jew-suspended-for-antisemitism-why-is-uk-labour-party-making-suchune (retrieved 1 Aug 2018). 
cellation ${ }^{57}$ on the same grounds I have cited to criticise the anti-Regev campaign. Non-viewpoint-selective grounds may legitimately be invoked to limit speech, such as unmanageable noise levels, crowd safety, and the like. ${ }^{58}$ As to criteria based solely on the viewpoint of the speaker, however, either the commitment is to freedom of all viewpoints, which I have elsewhere called viewpoint absolutism (Heinze, 2006; 2016), or it is to imposition of political viewpoints upon other members of the academic community: tertium non datur.

A further obstacle arises through the definition of antisemitism, and accompanying guidelines, adopted in 2016 by the International Holocaust Remembrance Alliance (IHRA) under the Romanian Chairmanship. According to that definition, "Antisemitism is a certain perception of Jews, which may be expressed as hatred toward Jews. Rhetorical and physical manifestations of antisemitism are directed toward Jewish or non-Jewish individuals and/or their property, toward Jewish community institutions and religious facilities." ${ }^{59}$ Within anti-discrimination law, defining groups, let alone capturing the typical character of hostility towards them, is never an exact science and always politically precarious (Heinze, 1995: 50-62). In addition, in view of concrete manifestations of antisemitism in the $21^{\text {st }}$ century (Benz, 2005), the IHRA's various interpretive guidelines are visibly drafted as responses to them. For example, according to one less controversial IHRA guideline, antisemitism includes "[c]alling for, aiding, or justifying the killing or harming of Jews in the name of a radical ideology or an extremist view of religion" (Heinze, 1995: 50-62).

More controversial is the inclusion, as a form of antisemitism, of "[d]enying the Jewish people their right to self-determination, e.g., by claiming that the existence of a State of Israel is a racist endeavor" (Heinze, 1995). Although people's rights to self-determination appear as a bedrock principle of international law, ${ }^{60}$ that doctrine's interpretation has been highly limited, with many claims rejected (Cassese, 2008). In addition, examining actual or plausibly racist elements in the prac-

57 The Occupation at 50: Past, Present, Futures, University of Sussex, 11-12 May 2017; Academic Freedom, International Law, and 'Balance', Sussex Centre for Human Rights Research Roundtable, 12 May 2016.

58 On the concept of "time, manner, and place" restrictions on speech, see, e.g., Nowak and Rotunda, 2009: 1447-1474.

59 See communication of 26 May 2016 at https://www.holocaustremembrance.com/sites/default/files/press_release_document_antisemitism.pdf(retrieved 1 Aug 2018).

${ }^{60}$ See, e.g., International Covenant on Economic, Social and Cultural Rights, G.A. res. 2200A (XXI), 21 U.N. GAOR Supp. (No. 16) at 49, U.N. Doc. A/6316 (1966), 993 U.N.T.S. 3, entered into force Jan. 3, 1976, art. 1(1); International Covenant on Civil and Political Rights, G.A. res. 2200A (XXI), 21 U.N. GAOR Supp. (No. 16) at 52, U.N. Doc. A/6316 (1966), 999 U.N.T.S. 171, entered into force Mar. 23, 1976, art. 1(1). 
tices of various states has remained central to historical research since the mid-20 $0^{\text {th }}$ century, notably in critical race theory and post-colonial studies. Scholars sympathetic to the Israeli state, and opposed to the singling out of Israel through boycotts and other mobilised actions, can nevertheless fairly examine racist histories in Israel not different in principle from those of many other states.

Many criticisms of Israel amount to antisemitism while others do not. A perilously grey area remains between those two stances. Some of the IHRA guidelines appear context-specific - more plausible in some contexts, less so in others. It is precisely such controversies that must be raised within the framework of academic discussion, and not as threshold criteria for precluding it. ${ }^{61}$ How far viewpoint absolutism must extend beyond open campus speech is a harder question. Allegations have arisen, for example, of censorship imposed through hiring and tenure decisions. ${ }^{62}$ Those involve further questions of employment law and of university hiring and tenure criteria, which, although vital to the present topic, will require separate examination.

\section{Challenging the Background Regime?}

My focus thus far has been on challenging the widespread view that universities ought to censor beyond what the law requires. The principle of viewpoint absolutism, by contrast, suggests that democratic universities ought to oppose such limits. The foregoing discussion has not examined non-democracies, nor weaker or transitional democracies, within which legitimate security concerns might arise (Heinze, 2016: 78-81), but has instead assumed longstanding, stable and prosperous democracies (LSPDs). Elsewhere I have challenged our tendencies to assume that liberal solutions and democratic solutions are interchangeable, arguing that they differ markedly in the terrain of free speech (ibid.: 88-91). Of course, "liberal" and "democratic" both mean many things, but the dominant liberal approach in Europe ordinarily takes the form of what I have called "value-pluralist balancing", whereby the

${ }^{61}$ See, e.g., Charlotte England, "Free speech on Israel is under threat from groups conflating criticism of country with anti-Semitism, say academics", The Independent, 1 March 2017, https://www.independent.co.uk/news/uk/home-news/free-speech-israel-anti-semitism-university-academics-criticisms-jews-palestinian-rights-a7605306.html (retrieved 1 Aug 2018).

${ }^{62}$ See, e.g., Claire Potter, "Racism and Tenure at MIT", The Chronicle of Higher Education, $18 \mathrm{Feb}$ 2007, http://www.chronicle.com/blognetwork/tenuredradical/2007/02/racism-and-tenure-at-mit-on-friday/ (retrieved 1 Aug 2018); Conor Friedersdorf, "Stripping a Professor of Tenure Over a Blog Post", The Atlantic, 9 Feb 2015, https://www.theatlantic.com/education/ archive/2015/02/stripping-a-professor-of-tenure-over-a-blog-post/385280/ (retrieved 1 Aug 2018); Robert Mackey, "Professor's Angry Tweets on Gaza Cost Him a Job", The New York Times, 12 Sept 2014, https://www.nytimes.com/2014/09/13/world/middleeast/professors-angrytweets-on-gaza-cost-him-a-job.html (retrieved 1 Aug 2018). 
message of the speech is weighed against other social values. To be sure, states and public universities must evaluate a range of factors in the regulation of speech, but I have argued that the one thing neither can do with democratic legitimacy is to "balance away" a particular message solely on grounds of its objectionable worldview. ${ }^{63}$

In contrast to an approach focussed on assessments of the viewpoint expressed, a distinctly democratic approach focusses on the forum of expression as a sphere of open exchange. The real problem with hate preachers or other extremists has not been their messages as such, but rather invitations on campuses without full community knowledge, in meetings sometimes having a secretive, semi-private character despite availing themselves of campus facilities. In pursuance of the academic mission, it is legitimate for the university to impose structural instead of viewpointselective criteria. First, for example, the university may legitimately require open identification of the sponsoring individual, organisation, or department. That step in itself constitutes the event's first speech act. It not only announces the occurrence of the event, but acknowledges a responsibility towards the campus community. Second, universities may legitimately prescribe designated channels, such as university websites and notice boards for ensuring adequate advertisement of events to the entire campus community. Third, universities may legitimately ensure open opportunities for all community members, or as many as possible, to attend by ensuring adequate spatial facilities. Fourth, universities may impose at least a presumption of timeframes for meaningful, more than cosmetic audience participation. The point is not that universities must do those things, but might legitimately do them in lieu of making elite assessments about the value of a particular speaker or message.

Note that, despite no-platformers' concerns about enforcing dominant power structures, one remarkable feature of university forums is how rarely senior corporate executives seek out such opportunities. It is unlikely that their absence is due solely to busy schedules, let alone lack of staff or student interest. Some of us would eagerly attend a debate with representatives of Monsanto or McDonalds. Rather, knowing the potential of a university forum for critical scrutiny, such executives presumably stay away - that is, they self-censor, without anyone else having to censor them - for reasons of image, reputation, and public relations. There is no fact of the matter as to whether university venues are forums for uncritical self-promotion and entrenchment of hierarchy. Whether they are or are not depends upon the academic community itself. When university forums are structured to prioritise scrutiny, some speakers will decline speaking invitations without censorship needing to be exercised.

${ }^{63}$ Cf. Konigsberg v. State Bar of California, 336 U.S. 36, 61 (1961) (Black, J., dissenting). 
Recall the first example cited above, namely, of David Irving and Nick Griffin invited to Oxford for a debate about free speech. Recall also that the Berkeley blowup was sparked by a "free speech week". Those are but two examples of a noticeable pattern. Once a university censors speakers, it is that censorship itself which then prompts controversies about whether there ought to be censorship. Suddenly figures like Irving and Griffin are invited not to make points about racism, where they are easily defeated and made to look incompetent, but instead to vindicate free speech, a core academic value which, in many eyes, starts to make them look like defenders of reason. Under the principle of viewpoint absolutism I have proposed, such figures would no longer need to be invited for the sole purpose of proving the value of free speech per se, because that value would remain untouched. There would no longer be any point to inviting them in their coveted, almost glamorous role of "free speech martyrs". Attention could instead remain focussed on - or rather, open challenges to - the actual ideas, which have made them controversial in the first place. Currently the law actively enables controversial speakers to mainstream their messages by drawing attention away from the extremist content towards a focus on their vindication of the democratic value of free speech. They end up becoming the democrats facing down un-democratic law.

No-platformers may respond that speaking events aimed at challenging extremists rarely change their minds. But the purpose of such events is not to stage Damascene conversions. Their aim is not the education of the speakers but of the audiences. The risk of perpetuating unequal power relations through campus speech is, in a word, not a matter of pre-destined fact but of collective will. Whether objectionable ideas blithely procreate or face the grilling of their lives is up to the university community itself. Far from seeking ever new opportunities to censor, public higher education must lead the way towards abolition of all viewpoint-selective censorship. No challenge is more eminently suited to the university's role and purpose.

\section{REFERENCES}

Ayer, Alfred J. 1952. Language, Truth and Logic. New York: Dover.

Barendt, Eric. 2007. Freedom of Speech (2nd ed.). Oxford: Oxford University Press.

Benz, Wolfgang. 2005. Was ist Antisemitismus? (2nd ed.). Munich: Beck.

Butler, Judith. 1997. Excitable Speech: A Politics of the Performative. New York: Routledge.

Cassese, Antonio. 2008. Self-Determination of Peoples: A Legal Reappraisal. Cambridge: Cambridge University Press. 
Dworkin, Andrea. 1981. Pornography: Men Possessing Women. New York: Putnam.

Freedman, Rosa. 2013. The United Nations Human Rights Council: A critique and early assessment. Oxford: Routledge.

Gould, Rebecca Ruth. 2018. Legal Form and Legal Legitimacy: The IHRA Definition of Antisemitism as a Case Study in Censored Speech. Law, Culture and the Humanities: 1-34.

Hare, Ivan and Weinstein, James (eds.). 2009. Extreme Speech and Democracy. Oxford: Oxford University Press.

Heinze, Eric. 1995. Sexual Orientation: A Human Right. Dordrecht: Nijhoff.

Heinze, Eric. 2006. Viewpoint Absolutism and Hate Speech. Modern Law Review, vol. 69: 543-582.

Heinze, Eric. 2008. Truth and Myth in Critical Race Theory and LatCrit: Human Rights and the Ethnocentrism of Anti-Ethnocentrism. National Black Law Journal, vol. 20: $107-162$.

Heinze, Eric. 2009. Cumulative Jurisprudence and Hate Speech: Sexual Orientation and Analogies to Disability, Age and Obesity. International Journal of Human Rights, vol. 12: 193-209.

Heinze, Eric. 2016. Hate Speech and Democratic Citizenship. Oxford: Oxford University Press.

Heinze, Eric. 2017a. Taking legitimacy seriously: A return to deontology. Constitutional Commentary, vol. 32: 631-650.

Heinze, Eric. 2017b. Towards a general theory of law and historical discourse, in: Belavusau, U. and Gliszczyńska-Grabias, A. (eds.): Law and Memory: Towards Legal Governance of History. Cambridge: Cambridge University Press: 413-433.

Heinze, Eric. 2017c. Are you sitting comfortably? How safe spaces became dangerous. Free Speech Debate. https://freespeechdebate.com/discuss/are-you-sitting-comfortably-how-safe-spaces-became-dangerous/.

Heinze, Eric. 2018. Karl Marx's Theory of Free Speech. Humanity Journal (two parts), https://wp.me/p4FPzO-2Sx (retrieved 1 Aug 2018).

Henley, Jon and Ullah, Arreb. 2015. Marine Le Pen's Oxford university speech delayed by protesters, The Guardian, https://www.theguardian.com/world/2015/feb/05/marine-le-pen-front-national-oxford-union-university-speech-delayed-protesters (retrieved 1 Aug 2018).

Herz, Michael and Molnar, Peter (eds.). 2012. The Content and Context of Hate Speech: Rethinking Regulation and Responses. Cambridge: Cambridge University Press.

Heyman, Steven J. 2009. Hate Speech, Public Discourse, and the First Amendment, in: Hare, I. and Weinstein, J. (eds.): Extreme Speech and Democracy. Oxford: Oxford University Press: 158-181. 
Howe, Adrian. 1998. Review of Judith Butler, Excitable Speech. International Journal for the Semiotics of Law, vol. 11, no. 31: 95-104.

Josende, Lauriane. 2010. Liberté d'expression et démocratie: Réflexion sur un paradoxe. Brussels: Bruylant.

MacKinnon, Catharine A. 1996. Only Words. Cambridge, MA: Harvard University Press.

Mill, John Stuart. 1991. On Liberty, in: On Liberty and Other Essays. Oxford: Oxford University Press.

Marx, Karl. 1956a. Bemerkungen über die neueste preußische Zensurinstruktion, in: Karl Marx - Friedrich Engels: Werke. Berlin: Dietz, vol. 1: 3-27.

Marx, Karl. 1956b. Zur Judenfrage, in: Karl Marx - Friedrich Engels: Werke. Berlin: Dietz, vol. 1: 347-377.

Matsuda, Mari. 1993. Words That Wound: Critical Race Theory, Assaultive Speech, and the First Amendment. Boulder, CO: Westview Press.

Nieuwenhuis, Aernout. 2011. Over de grens van de vrijheid van meningsuiting: Theorie, rechtsvergelijking, discriminatie, pornografie (3rd ed.). Nijmegen: Ars Aequi Libri.

Noorloos, Marloes. 2012. Hate Speech Revisited: A Comparative and Historical Perspective on Hate Speech Law in the Netherlands and England \& Wales. Mortsel, BE: Intersentia.

Nowak, John E. and Rotunda, Roland D. 2009. Constitutional Law (8th ed.). St. Paul, Minnesota: West.

Pech, Laurent. 2003. La liberté d'expression et sa limitation: Les enseignements de l'expérience américaine au regard d'expériences européennes. Clermont-Ferrand: Les Presses Universitaires de la Faculté de Droit de Clermont-Ferrand.

Post, Robert. 1995. Constitutional Domains: Democracy, Community, Management. Cambridge, MA: Harvard University Press.

Post, Robert. 2006. Democracy and Equality. Annals of the American Academy of Political and Social Science, 603: 24-36.

Post, Robert. 2011a. Participatory Democracy and Free Speech. Virginia Law Review, 97 (3): 477-490.

Post, Robert. 2011b. Participatory Democracy as a Theory of Free Speech: A Reply. Virginia Law Review, 97 (3): 617-632.

Preuß, Urlich K. 2002. Die empfindsame Demokratie, in: Leggewie, C. and Meier, H. (eds.): Verbot der NPD oder mit Rechtsradikalen leben? Frankfurt a.M.: Suhrkamp: 104-119.

Rohrßen, Benedikt. 2009. Von der "Anreizung zum Klassenkampf” zur "Volksverhetzung” (\$ 130 StGB): Reformdiskussion und Gesetzgebung seit dem 19. Jahrhundert. Berlin: De Gruyter.

Scott, Joan W. 2017. On Free Speech and Academic Freedom. AAUP Journal of Academic Freedom, vol. 8: 1-13. 
Siddique, Haroon. 2015. University event questioning Israel's right to exist is cancelled, https://www.theguardian.com/uk-news/2015/mar/31/southampton-university-cancels-event-questioning-israel-existence (retrieved 1 Aug 2018).

Spitzer, Robert J. 2012. The Politics of Gun Control. New York: Routledge.

Strossen, Nadine. 1990. Regulating Racist Speech on Campus: A Modest Proposal. Duke Law Journal, vol. 39: 484-549.

Sunstein, Cass. 2003a. The Law of Group Polarization, in: Fishkin, J. and Laslett, P. (eds.): Debating Deliberative Democracy. Oxford: Blackwell Publishing: 80-101.

Sunstein, Cass. 2003b. Why Societies Need Dissent. Cambridge, Mass.: Harvard University Press.

Taylor, M. et al. 2007. Protesters force their way into Oxford Union, The Guardian, https://www.theguardian.com/uk/2007/nov/26/humanrights.thefarright (retrieved 1 Aug 2018).

Thiel, Markus (ed.). 2003. Wehrhafte Demokratie: Beiträge über die Regelungen zum Schutze der freiheitlichen demokratischen Grundordnung. Tübingen: Mohr Siebeck.

Trömel-Plötz, Senta (ed.). 1984. Gewalt durch Sprache: Die Vergewaltigung von Frauen in Gesprächen. Frankfurt a.M.: Fischer.

Tsesis, Alexander. 2002. Destructive Messages: How Hate Speech Paves the Way for Harmful Social Movements. New York: New York University Press.

Vaneigem, Raoul. 2003. Rien n'est sacré, tout peut se dire: Réflexions sur la liberté d'expression. Paris: La Découverte.

Waldron, Jeremy. 2012. The Harm in Hate Speech. Boston, MA: Harvard University Press.

Weale, Sally. 2017. Fears Israeli ambassador's visit to Soas may spark unrest, The Guardian, https://www.theguardian.com/education/2017/apr/25/israeli-ambassador-mark-regev-soas-university-of-london (retrieved 1 Aug 2018).

Weinstein, James. 1999. Hate Speech, Pornography, and the Radical Attack on Free Speech Doctrine. Boulder, CO: Westview Press.

Weinstein, James. 2011a. Participatory Democracy as the Central Value of American Free Speech Doctrine. Virginia Law Review, 97 (3): 491-514.

Weinstein, James. 2011b. Participatory Democracy as the Basis of American Free Speech Doctrine: A Reply. Virginia Law Review, 97 (3): 633-679.

Mailing Address: Eric Heinze, Professor of Law \& Humanities, School of Law, Queen Mary, University of London, Mile End Road, London E1 4NS. E-mail: e.heinze@qmul.ac.uk 